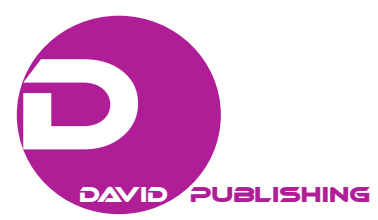

\title{
Reading Excavated Laozi: The Lens of Western Scholarship ${ }^{*}$
}

\author{
Ka-lai Chan \\ Shandong University, Jinan, Shandong, China
}

\begin{abstract}
There has been an increasing interest in the Chinese excavated documents of western scholars. With different version of excavated Laozi, it attracts the attention of researchers. This paper examines the study of unearthed Laozi by western scholars by using Mawangtui and Guodia Laozi,attempts to give readers a basic picture of unearthed Laozi study in western academia.Since there is no way that I can hope to introduce all western studies of unearthed Laozi, this paper will restrict the presentation to just the following topic: Mawangtui Laozi, Guodian Laozi, "Tai Yi Sheng Shui”, "Wu Xing”, and Methodology.
\end{abstract}

Keywords: Laozi, Excavated Laozi, Chinese Unearthed Documents

\section{Introduction}

The purpose of this article is to give a relatively comprehensive survey of western Sinologists' studies of Laozi (老子) from the pre-Qin through Han periods. This idea comes from an article written by Martin Kern and he raises a question that deserves attention (Kern, 2019). He points out monolingualism and monoculturalism are the fundamental limitations of the current ancient Chinese studies in Mainland China. Too many Chinese scholars cannot master any foreign languages. Even if a translation works has been published, Chinese scholars have so far paid very little attention to them. Of course, many translation works also have mistranslations.

I believe the problems he mentioned are common in Mainland China nowadays. Therefore, I hope to use this article to introduce the study of excavated Laozi of scholars in Western academia to Chinese scholars. I do not believe that the West must be stronger than Chinese scholars in China studies. But today, in the globalization era of the 21st century, Chinese scholars do not pay attention to the results of Western scholarship, they just stop their own feet and have no benefit to academics.

In this paper, I want to first elaborate briefly on Mawangtui (馬王堆) and Guodian (郭店) archaeological discoveries, introduce excavated Laozi in these two discoveries; secondly, I will present methodology study on this topic, and thirdly, I will provide a reconsideration on reading excavated Laozi.

No one will quest the importance of Mawangtui and Guodian archaeological discoveries for the study of excavated Laozi. In the last months of 1973 two texts of the Laozi were found in a cache of manuscripts written on silk in Han Tomb No.3 at Mawangtui in Changsha (長沙), Hunan (湖南) Province (Xiao, 1974). The Silk Manuscripts provide us with two versions of the Laozi. Based upon a study of tabooed words, the experts state

\footnotetext{
*Acknowledgements: This paper was supported by “The Fundamental Research Funds of Shandong University” (Grant number 2019HW017). I would also like to take this opportunity in memory of Miss Fan Wai Shan, San. A respected best friend and a lovely lady who always supports my research and encourages me to learn French and German but unfortunately passed away on March 26, 2019. I trust she will be happy to read this article because it uses French and German materials.

Ka-lai Chan, Advanced Institute of Confucian Studies, Shandong University, Shandong, China
} 
that version A, which is written in seal script, must have been completed no later than 195 B.C., and that version B, in clerical script, may have been written between 194 and 180 B.C., thus representing by far the oldest extant texts of the Taoist classic. After thirty years of Mawangtui discovery, another Laozi text unearthed from a tomb near Guodian, Hubei (湖北) Province. After archeologists from the Jingzhou (荊州) Museum received news that tomb robbers had disturbed a tomb in a cemetery at the village of Guodian, they formally excavated the tomb, discovering that it was a Chu (楚) tomb from the transition period between the mid and late Warring States period (i.e., c. 300 B.C.), and that it contained over 700 bamboo strips with writing on them (Wang \& Tang, 1997). Guodian proves ideal for a qualitative study of text and thought in Warring States China. The texts were part of a tomb assemblage and came to light during a documented excavation. As many scholars argue, they have in common the endeavor to establish stable philosophical concepts. They were part of a discipline and may be termed broadly "philosophical”. To date, Guodian One is the only well-documented Warring States tomb to contain a variety of such texts (Meyer, 2012).

\section{Mawangtui}

As we know, Laozi is said to be the world's second-most frequently translated book (after the Bible), with more than 200 different translations just in western languages. There have already been at least six translations of Mawangdui Laozi, listed below:

- LANCIOTTI, Lionello. Libro della Virtùe della Via: Il Te-tao-ching secondo il manoscritto di Ma-wang-tui. Milano: Editoriale Nuova, 1981.

- LAU, D.C. Chinese Classics: Tao Te Chin. Hong Kong: The Chinese University Press, 1982.

- HENRICKS, Robert G. Te-Tao Ching: A New Translation Based on the Recently Discovered Ma-wang-tui Texts. New York: Ballantine Books, 1989.

- MAIR, Victor. Tao Te Ching: The Classic Book of Integrity and the Way. New York: Bantam Books, 1990.

- MÖLLER, Hans-Georg. Laotse, Tao Te King: Die Seidentexte von mawangdui. Franfurt a.m.: Fischer, 1995.

- ERSTNER, Ansgar."Enie Synopse und kommentierte Übersetzung des Buches Laozi sowie eine Auswertung seiner kritischen Grundhaltung auf der Grundlage der Textausgabe Wang Bis, der beiden Mawangdui-Seidentexte und unter Beröcksichtigung der drei Guodian-Bambustexte.” Ph.D. diss., Trier University, 2001.

There is no doubt that the discovery of Mawangdui has caused extremely widespread concern. These translations also have their own features. D.C. Lau published an English translation of Laozi in 1963 and was been read by western readers. In 1982 volume, of course, it is different from the 1963 one, but in general, the differences are not manifest. Comparing D.C. Lau, Henricks’s 1989 translation is at least more influential in the United States. From 1979 to 1999, he published at least six papers on Mawangdui Laozi. Most of his research has inherited the work of Chinese scholars. At least it can be said that his research methods are not much different from Chinese scholars (Shaughnessy, 2019, p. 291). The most peculiar is surely that by Victor Mair. He has in-depth research on Dunhuang (敦煌) transformation texts and believes that Buddhist preachers have a wide influence on Chinese culture. He argued that many of the basic terms in the Laozi are related to Indo-European languages, such as: “track” and “trek”; “德” and “doughty”; “得” and “integrity”; “經” and "filament" or "file". His translation was done for a general readership, and the discussion of the etymology of these words was provided in an article (Mair, 1990). 
Several German scholars also published studies of the Mawangdui Laozi manuscripts, listed below:

- OMMERBORN, Wolfgang et al. "Exemplarische Bearbeitung der Laozi-Seide Manuskripte (Version A und B) von Mawangdui anhand des tradierten Kapitels 39.”Bochumer Jahrbuch zur Ostasienforschung, 11 (1988): 213-267.

- M Ö LLER, Hans-Georg. Verschiedene Versionen des Laozi: Ein Vergleich mit besonderer Berücksichtigung des 19. Kapitels.”Monumenta Serica 47 (1999): 285-302.

- RICHTER, Matthias. "Towards a Profile of Graphic Variation: On the Distribution of Graphic Variants within the Mawangdui Laozi Manuscripts.” Asiatische Studien 59.1(2005): 169-207.

- RICHTER, Matthias. "Der Alte und das Wasser: Lesarten von Laozi 8 imüberlieferten Text und in den Manuskripten von Mawangdui."Han-Zeit: Festschrift für Hans Stumpfeldt aus Anlaß seines 65. Geburtstages. Lun Wen: Studien zur Geistesgeschichte und Literatur in China 8. Eds. Friedrich et al. Wiesbaden: Harrassowitz, 2006. 253-73.

Special attention should be paid to Matthias Richter, his papers propose an extremely rigorous paleographic methodology for dealing with variants within the Mawangdui Laozi manuscripts, with numerous implications for the writing and reading of all manuscripts (Shaughnessy, 2019, p. 296).

Many scholars have discussed the early Chinese intellectual history in the text of Mawangdui Laozi $B$ scroll. The first one must be given place for A.C. Graham's "A Neglected Pre-Han Phiosophical Text: Ho-kuan-tzu."1 He was the pre-eminent historian of ancient Chinese thought after the Second World War. Unfortunately, before he died he was able to see only the manuscripts of Mawangdui, and was able tofully digest those manuscripts let alone the many unearthed manuscripts that China had seen in the past two decades. In this article, he made use the "Yellow Emperor's Four Classics (黃帝四經)" to explore the authenticity and intellectual background of He guan zi (鶡冠子). Although his research inherits the views of some scholars in China, it is still very inspiring.

\section{Guodian}

In the few years since the Guodian manuscripts were unearthed (1993) ${ }^{2}$ and published (1998), ${ }^{3}$ they have already been hailed as being startling significance for the study of early Chinese intellectual history. Guodian manuscripts proves ideal for a qualitative study of text and thought in Warring States China.

Described as China's equivalent of the Dead Sea Scrolls, the Guodian Chu slips are significant in many ways (Allan \& Williams, 2000). The Guodian corpus is to date the only excavated cache of manuscripts that are exclusively philosophical in content. They constitute one of the very few finds that can safely be dated to the Warring States period, a crucial time in the history of Chinese thought(Chan, 2019, p. 6).

As of 2015, at least three books have been featured and discussed on Guodian bamboo slips, they are:

- HOLLOWAY, Kenneth W. Guodian: The Newly Discovered Seeds of Chinese Religious and Political Philosophy. Oxford: Oxford University Press, 2009.

\footnotetext{
1 In Bulletin of the School of Oriental and African Studies 52.3 (1989), pp. 497-509.

2 In October 1993, about 800 bamboo slips were discovered in a tomb located south of a mound in Guodian to the east of Mount $\mathrm{Ju}$ (紀山), where only nine kilometers north of the old capital of the state of Chu (楚). See Liu Zuxin (劉祖信) and Long Yongfang (龍永芳),Guodian Chujian zonglan(郭店楚簡綜覽), Taibei: Wanjuan Lou, 2005, p. 1.

3 The recovered cache of texts comprises a total of 804 bamboo slips, of which 730 are intact, and bear 12,072 Chu-script graphs, which it is assumed, were brush-written on the bamboo slips close to the time of burial. See Jingmenshi Bowuguan (荊門市博物 館) ed., Guodian Chumu zhujian(郭店楚墓竹簡), Beijing: Wenwu Chubanshe, 1998, p. 1.
} 
- MEYER Dirk. Philosophy on Bamboo: Text and the Production of Meaning in Early China. Leiden: Brill, 2012.

- COOK Scott. The Bamboo Texts of Guodian: A Study and Complete Translation. Ithaca, N.Y.: East Asia Program, Cornell University, 2012.

It is necessary to make a simple explanation for these three books.

In 2002, Kenneth W. Holloway submitted his doctoral thesis entitled "The recently discovered Confucian classic 'The Five Aspects of Conduct'” to the University of Pennsylvania, and published several articles about Guodian bamboo Slips after that. His 2009 book Guodian: The Newly Discovered Seeds of Chinese Religious and Political Philosophy is the first western monograph devoted to the Guodian bamboo slips, and thus attracted no little attention. In 2019, he published an article to discuss the Guodian manuscripts has a coherent religious philosophy (Holloway, 2019, pp. 355-369).

Dirk Meyer's 2011 book also based on his doctoral dissertation. His consists of three parts. Part I provides a detailed form analysis of the argument-based texts from Guodian One. He hopes to show that approaching early texts from the perspective of their formal structure is methodologically important for dealing with the written ideas from the early periods. Part II discusses the intellectual environment of the written materials from the Guodian One corpus. The focus of the discussion is on the relationship between material conditions of text, manuscript culture, and writing, as well as on the strategies of meaning construction and philosophizing, in the Warring States period. Part III provides philological justification of my reconstruction of the texts considered in this study (Meyer, 2012, pp. 26-28).

Scott Cook's 2012 book has twovolumes. This giant two-volume book is more than a thousand pages long. It can be said that Cook examined everything that was published in the fourteen years between the initial publication of Guodian Chu jian and the publication of Cook's own book. The subtitle of this book well describes the content of the book. "Study" refers the first 185 pages of the Introduction in volume I and to explain the discovery of Guodian bamboo slips and the ideological background of the Warring States Period. "Complete Translation" includes not only a translation, but also with detailed annotation. His translation not only aggregates the research results of others, but also makes his own judgments and research on each sentence(Shaughnessy, 2019, p. 344).

\section{“Tai Yi Sheng Shui” (太一生水) “The Ultimate One Gives Birth to Water” and “Wu Xing” (五行) “Five Aspects of Virtuous Conduct”}

For western scholars, the most interesting is the idea about cosmogenesis in "Tai yi sheng shui”. The most influential one should be Allan's research. In 2003, she published an article entitled "The Great One, Water, and the Laozi: New Light from Guodian” on the authoritative journal T'oung Pao (Allan, 2003), which provides a detailed study of the text, cosmology and mythology of "Tai yi sheng shui”. Like many scholars, she advocates that "Tai yi sheng shui" proposed a theory of cosmology. However, she linked this cosmology to the Laozi, saying that the shi (式) (shipan (式盤) in modern Chinese) in Laozi should be the shipan (式盤) of the device. It was the model of the universe. She even suggested that the original meaning of "Dao" (道) was not a "roadway" but a "waterway", and it was the root metaphor of the philosophical concept. Philosophically, Dao was a natural course or way, grounded in the imagery of the stream of a river or of the water bubbling up unceasingly from a natural spring. One of the characteristics of water was that it flows in channels and always moves downward. From this idea of the Dao, modeled on the image of a stream with a spring as its source, its 
channel acting as a conduit that guides people in their actions, the concept was extended to encompass a condition in which everything in the world follows its natural course.

The Wuxing text is one of the main Guodian texts that clearly emphasizes the divine-human connection, attempting to weave human behavior into the larger fabric of a cosmos that is at once spiritual and ethical. ${ }^{4}$ Scott Cook's paper entitled "Consummate Artistry and Moral Virtuosity: The 'Wu xing' Essay and Its Aesthetic" (Cook, 2000, pp. 113-146) is quite remarkable. It analyzes the different between Mawangdui and Guodian "Wu xing" texts. He also points out that after the unearthing of the Guodian "Wu xing”, we did realize the relationship between jin (經, classic) and zhuan (傳, commentary). Cook has a musical background and was trained in music when he was in university. His master's thesis Yue Ji (樂記), giving both a translation of the text and also a probing discussion of it. ${ }^{5}$ In 1995, his doctoral thesis was titled "Unity and Diversity in the Musical Thought of Warring States China”. Therefore, the text of the "Wu xing” of Mawangdui often uses music to symbolize self-cultivation to attract the attention of Cook.

\section{Methodology}

Western sinologists are particularly concerned with the methodology of unearthed philology and paleography, suggesting a series of methods and principles. They have a lot of examples using the unearthed Laozi to do this, which deserves our attention.

In the book of The Guodian Laozi: Proceedings of the International Conference, Dartmouth College, there are several articles that use the example of Laozi as a methodologic. Because these are studies of two decades ago, in order to save space, I only listed the title of related articles in preparation for reference.

- BOLTZ, William G. “The Study of Early Chinese Manuscripts Methodological Preliminaries.” pp. 39-52.

- ROTH, Harold D. "Some Methodological issues in the Study of the Guodian Laozi Parallels.” pp. 71-88.

- THOMPSON, P. M. “On the Formal Treatment of Textual Testimony.” pp. 89-106.

I must point out that Western sinologists often use Laozi as an example to discuss methodological issues. In the article entitled "Reading the Early Laotzyy", William Boltz made a very interesting reflection and raised many questions:

The natural inclination for some scholars and students was to be skeptical of both extremes and to look instead for textually sound interpretations of whatever implication. The catch here was that knowing how to judge competing explanations of the textual differences and how to assess the respective competing claims about the meaning of the text was unfamiliar territory for most of us. Identifying and classifying what kinds of differences there might be, what their impact was, both individually and in the aggregate, deciding which of these might be significant, and even knowing how to define "significance", were experiments in textual criticism that, for many of us, were completely new. Not only were we largely untrained in the theory and methods of textual criticism, the field of textual criticism itself had in most respects not been explicitly developed or elucidated in any systematic or comprehensive way in western scholarship on early Chinese texts. There was, in short, very little recognized scholarly method for the study of early Chinese manuscripts in comparison with what had been established in the course of more than a century of philological and textual research in the world of classical Mediterranean or ancient Near Eastern texts.

As study progressed, the question of how to assess the significance of these manuscripts received increasing attention. Did the value of the newly discovered manuscripts lie in their capacity to correct the received text, providing alternative

\footnotetext{
4 Jingmenshi Bowuguan, ed., Guodian Chumu zhujian, pp. 149-154.

5 He wrote his Master's thesis in 1990 on the Yue Ji, the earliest fully-developed extant treatise on music, which was written no later than the middle of the Western Han and is thought to contain a large amount of Warring States period material dealing with music. See Marco Caboara, “Book Review: The Bamboo Texts of Guodian: A Study \& Complete Translation,” Journal of Chinese Studies, 59 (July 2014), pp. 253-254.
} 
readings that in the aggregate gave different interpretations to the text, or did these manuscripts with their apparent differences serve instead to validate a traditional understanding based on the received text? Or, possibly, is there a kind of "middle road" that recognizes the difference between these two extremes, allowing the traditional understanding of the received text to stand and yet establishing alternative readings of the seemingly same text, based on the manuscript evidence? Do variants reflect competing "schools” or doctrinal preferences or are they simply the consequences of careless and poorly informed textual transmission? Or some of both? Is it the job of the editor to use the manuscripts only to correct details of the received text, or conversely to show from the evidence of the received text the errors of the manuscript and thus to explain away as many of the variants as possible? Or should the primary goal be to try to establish through comparison of the manuscripts with the received text a version of the original as close as possible to what the author first wrote? In what sense can we, in fact, even talk about an "original” text and an "author”? To adopt these terms uncritically from other textual traditions might actually blind us to some of the most interesting implications that could arise from studying these manuscripts. (Boltz, 2005, pp. 213-214)

Although these questions do not have an exact answer, they are still worth asking.

In addition, Matthias Richter should be the scholar who attaches the most importance to the material properties of the manuscripts. In a series of articles listed below, he made a very detailed examination of the both transmitted and the unearthed manuscripts.

- "Handschriftenkundliche Probleme beim Lesen altchinesischer Manuskripte." Aspekte des Lesens in China in Vergangenheit und Gegenwart: Referate der Jahrestagung 2001 der Deutschen Vereinigung für Chinastudien (DVCS). Ed. Bernhard Führer. Edition Cathay 54. Bochum: Projekt, 2005, pp. 88-121.

- "Towards a Profile of Graphic Variation: On the Distribution of Graphic Variants within the Mawangdui Laozi Manuscripts.” Asiatische Studien 59.1 (2005): 169-207.

- "Tentative Criteria for Discerning Individual Hands in the Guodian Manuscripts." Rethinking Confucianism: Selected Papers from the Third International Conference on Excavated Chinese Manuscripts, Mount Holyyoke College, April 2014. Ed. Wen Xing. San Antonio: Trinity University, 2006, 132-47.

- "Faithful Transmission or Creative Change: Tracing Modes of Manuscript Production from the Material Evidence.” Asiatische Studien 63.4 (2009): 889-908.

- "Textual Identity and the Role of Literacy in the Transmission of Early Chinese Literature." Writing and Literacy in Early China: Studies from the Columbia Early China Seminar. Eds. Li Feng and David Prager Branner. Seattle and London: University of Washington Press, 2011, pp. 206-36.

- The Embodied Text: Establishing Textual Identity in Early Chinese Manuscripts. Leiden: Brill, 2013.

In the two articles that were published in 2005, Richter examined the textual variants contained in the two of Mawangdui's Laozi, and thought that we can know from the variations how the manuscripts are caused. He points out that in the Laozi B manuscript, the character zhu(主) serves as a very first example. Two types of what is structurally the same character are used in the Mawangdui manuscripts to write the character zhu: one has a dot on top and the other a horizontal stoke. Usually shorter than the three horizontals below. B Mawangdui has both forms. In the beginning, the first stroke is written as a dot just like in most other Mawangdui manuscripts; later the other form with a line on top gains dominance and is finally written exclusively. But even then the character continues to change-at the beginning of the manuscript the horizontal line on top is markedly shorter than the lower three horizontals, but further down in the manuscript it gets longer and finally reaches almost the same length (Richter, 2005).

\section{A Concluding Speculation}

Undoubtedly, I can’t fully introduce the western Sinologist's study of the excavated Laozi in an article. I 
received my academic training in China study in Hong Kong and the United States. I value traditional Chinese materials and am not unfamiliar with western academic achievements. Looking back the beginning of the article which monolingualism issue mentioned by Martin Kern, I still want to give an example to summarize the article. Ge Zhaoguang (葛兆光) says in an article that he "is very eager to see the first one to do research on China study is a Chinese people, but I still regret to say that Taoist studies started from foreign countries 很希 望治本國學問的最早是本國人, 但這裡我還是很遺憾地說, 現代學術意義上的道教研究, 是從外國開始 的.” (Ge, 2013, p. 75). I would like to ask: Is there any regrettable matter about foreign scholars doing research on China study? Ignoring the achievements of foreign scholars is a rather naive academic attitude. If foreign scholars contribute to China study, this should not be a regrettable matter, but should be welcomed and widely publicized by Chinese scholars, because it shows that Chinese culture is a culture that the world values and cares.

Finally, allow me to end this article with two sentences from Guodian "Wu xing",

仁之思也清, 精則察, 察則安, 安則溫, 溫則悅, 悅則戚, 戚則親, 親則愛, 愛則玉色, 玉色則形, 形則仁

智之思也長, 長則得, 得則不忘, 不忘則明, 明則見賢人, 見賢人則玉色, 玉色則形, 形則智

A benevolence man and a wise man reach the same goal by different means although their interests are different. We hope that Chinese and foreign scholars can join hands and cooperate with each other.

\section{References}

Allan, S. (2003). The great one, water, and the Laozi: New light from Guodian. T'oung Pao, 89(4-5), 237-285.

Allan, S., \& Williams, C. (2000). The Guodian Laozi: Proceedings of the international conference, Dartmouth College, May 1998. Berkeley: Society for the Study of Early China and the Institute of East Asian Studies, University of California.

Boltz, W. G. (2005). Reading the early Laotzyy.Asiatische Studien / Études Asiatiques, 59(1), 213-214.

Chan, S. (2019). Introduction: The excavated Guodian bamboo mauscripts. In Dao Companion to the Excavated Guodian Bamboo Manuscripts (p. 6). Cham: Springer.

Cook, S. (2000). Consummate artistry and moral virtuosity: The 'Wu xing'五行 essay and its aesthetic. Chinese Literature: Essays, Articles, Review, 22, 113-146.

Ge, Z. G. (2003). Guan yu daojiao yanjiu de lishi he fangfa關於道教研究的歷史和方法. Zhongguo dianji yu wenhua 中國典籍 與文化, 1,75 .

Holloway, K. W. (2009). Guodian: A New Window for Understanding the Introduction of Buddhism into China. In Dao Companion to the Excavated Guodian Bamboo Manuscripts (pp. 355-369). Cham: Springer.

Kern, M. (2019). Zaoqi Zhongguo wenxian yanjiu fangfa zhifansi早期中國文獻研究方法之反思. In X. G. Liu, et al. eds., Jianbo Sixiang Wenxian Yanjiu 簡帛思想文獻研究 (pp. 122-155). Beijing: Dongfang chubanshe.

Mair, V. H. (1990). [The] File [on the Cosmic] Track [and Individual] Dough [tiness]: Introduction and Notes for a Translation of the Ma-wang-tui Manuscripts of the Lao-tzu.Sino-Platonic Papers. Philadelphia: Department of Oriental Studies, University of Pennsylvania.

Meyer, D. (2012). Philosophy on bamboo: Text and the production of meaning in early China (pp. 4-5). Leiden: Brill.

Richter, M. L. (2005). Towards a profile of graphic variation: On the distribution of graphic variants within the Mawangdui Laozi manuscripts. Asiatische Studien / Études Asiatiques,59(1), 177-178.

Shaughnessy, E. L. (2019). Chinese annals in the western observatory: An outline of western studies of Chinese unearthed documents (p. 291). Berlin: Walter de Gruyter.

Wang, C. F., \&Tang, X. F. (1997). Jingmen Guodian yihao Chumu荊門郭店一號楚墓. WenWu文物, 7, 35-48.

Xiao, H. (1974). Zhangsha Mawangdui hanmu boshu gaishu長沙馬王堆漢墓帛書概述. WenWu文物, 9, 40-44. 